\title{
Fertilization Strategies Based on Climate Information to Enhance Food Security Through Improved Dryland Cereals Production
}

\author{
Komla Kyky Ganyo, Bertrand Muller, Aliou Guissé, and \\ Myriam Adam
}

\section{Contents}

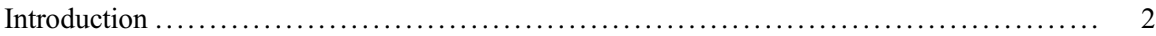

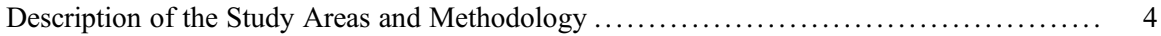

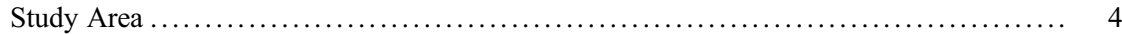

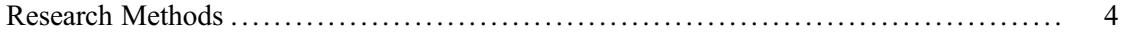

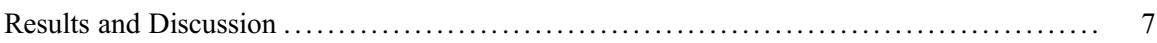

Development and Growth Parameters ...................................... 7

Yield, Plant Biomass, Harvest Index, and Response Index ....................... 8

Grain Yield Simulations ................................................ 15

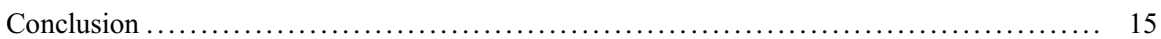

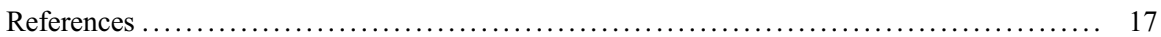

K. K. Ganyo ( $\square)$

Centre d'Etude Régional pour l'Amélioration de l'Adaptation à la Sécheresse (CERAAS), BP, Thiès, Sénégal

Institut Togolais de Recherche Agronomique (ITRA), Lomé, Togo

e-mail: desireganyo@gmail.com

B. Muller

Centre d'Etude Régional pour l'Amélioration de l'Adaptation à la Sécheresse (CERAAS), BP, Thiès, Sénégal

Centre de Coopération Internationale en Recherche Agronomique pour le Développement (CIRAD), UMR AGAP/PAM, Montpellier, France

A. Guissé

Département de Biologie Végétale, Université Cheikh Anta Diop de Dakar (UCAD),

Dakar, Sénégal

M. Adam

Centre de Coopération Internationale en Recherche Agronomique pour le Développement (CIRAD), UMR AGAP/PAM, Montpellier, France

Institut de l'Environnement et de la Recherche Agricole (INERA), Bobo Dioulasso, Burkina Faso International Crops Research Institute for Semi-Arid Tropics (ICRISAT), Bamako, Mali 


\section{Abstract \\ Rainfall uncertainty and nutrient deficiency affect sorghum production in Sahel. This study aimed at (i) determining the responses (varieties*water*nitrogen) of various West-African sorghum (Sorghum bicolor L. Moench) varieties to the application of fertilizer (NPK and urea) at selected growing stages according to water regime (irrigated or not, different rainfall patterns) and (ii) simulating them to define alternative fertilization strategies. This chapter proposes alternative fertilization strategies in line with rainfall patterns. Split plot experiments with four replications were carried out in two locations (Senegal), with four improved sorghum varieties (Fadda, IS15401, Soumba and 621B). Treatments were T1, no fertilizer; T2 $=150 \mathrm{~kg} / \mathrm{ha}$ of NPK $(15-15-15)$ at emergence $+50 \mathrm{~kg} / \mathrm{ha}$ of urea $(46 \%)$ at tillering $+50 \mathrm{Kg} / \mathrm{ha}$ of urea at stem extension; $\mathrm{T} 3=$ half rate of $\mathrm{T} 2$ applied at the same stages; T4 $=150 \mathrm{~kg} / \mathrm{ha}$ of NPK $+50 \mathrm{~kg} / \mathrm{ha}$ of urea at stem extension $+50 \mathrm{~kg} / \mathrm{ha}$ of urea at heading, and $\mathrm{T} 5=$ half rate of $\mathrm{T} 4$ applied at the same stages. Plant height, leaf number, grain yield, and biomass were signifi- cantly affected by the timing and rate of fertilizers. Grain yield were affected by water*nitrogen and nitrogen*variety interactions. It varied from 2111 to $261 \mathrm{~kg} /$ ha at "Nioro du Rip" and from 1670 to $267 \mathrm{~kg} / \mathrm{ha}$ at "Sinthiou Malème". CERES- Sorghum model overestimated late fertilizer grain yields. To achieve acceptable grain yield, fertilizers application should be managed regarding weather.}

\section{Keywords}

Fertilization strategies $\cdot$ Climate information $\cdot$ Food security $\cdot$ Sorghum $\cdot$ Sahel $\cdot$ Modeling

\section{Introduction}

Climate is the most important factor that governs food production and is considered as the most weather dependent of all human activities (Hansen 2002) that impacts food security (Tubiello et al. 2007). The severity of climate uncertainties is particularly strong in Sahel where rainfed agriculture is the main source of food and income (Defrance et al. 2017; Ingram et al. 2002). Cereals such as sorghum (Sorghum bicolor L. Moench) and millet (Pennisetum glaucum (L.) R. Br.) are the main staple foods for millions of people in tropical arid and semi-arid regions of Africa, Asia, and South America (Gueye et al. 2016). They are multipurpose cereals, with grain, forage, and sweet types (Almodares et al. 2007; Gnansounoua et al. 2005).

Although, sorghum and millet are described as rustic and well-adapted crops to tropical and subtropical zones (Legwaila et al. 2003; Bezançon et al. 1997; Kulkarni et al. 1995), cultivating these crops nowadays in Sahel comes with problems. The main limiting factors are nutrient deficiency, short rainy season, and interannual and intraseasonal rainfall variability. A consequence of this rainfall variability is the appearance of drought periods during the growing season (Casenave and Valentin 
1989). According to the Intergovernmental Panel on Climate Change (IPCC) fourth assessment report (AR4), climate change resulting in an increase of greenhouse gas emissions will accentuate rainfall uncertainty and extremes events such as extreme droughts, flooding, temperature increase in some parts of world (IPCC 2007). Both variability and change in climate affect food production availability, stability of food supplies, food utilization, access to food, and food prices everywhere in world (Schmidhuber and Tubiello 2007). Dealing with the uncertainty of climate is a challenge for agriculture in general and farmers in particular. Farmers in the Sahel perceiving risks in inputs investments due to unpredictable weather are still using little or no fertilizer, and local varieties, hence maintaining low production level. However, with population growth and increasing demand for food, maximizing crops productivity while minimizing losses and maintaining resilience is a complicated obligation.

To mitigate the effect of rainfall uncertainty and to adapt to droughts during the growing season, it is proposed to manage fertilizer application according to climate information and forecasts. Recent studies (Sultan and Gaetani 2016; Roudier et al. 2012; Sultan et al. 2010) indicated that seasonal forecasts could help to provide advises about varieties choice, sowing date, and inputs use. Roudier et al. (2012) showed that (i) predictions of long rainy season duration (onset and offset) and humid years exclude the use of millet short cycle cultivars because of damages occurring on early maturation and (ii) impact of fertilizer in humid years is positive on yields in South-West Niger. Therefore, forecasts about future climate might help African farmers to take crucial strategic decisions to reduce their vulnerability and increase farm profitability (Sultan et al. 2010).

Field studies on late fertilization showed promising results. Bodson et al. (2003) studied the split of $\mathrm{N}$ fertilizer on wheat and found that applying $\mathrm{N}$ fertilizer twice at stem elongation and at flag leaf stages gave similar yields with higher grain quality compared to traditional practice (three applications at tillering, stem elongation, and leaf flag stages). Perez et al. (1996) reported an increase rough rice yield by $6 \%$ and head rice yield by $17 \%$ with an additional $\mathrm{N}$ application of $30 \mathrm{~kg}$ of $\mathrm{N} / \mathrm{ha}$ at flowering. Wuest and Cassman (1992) compared the uptake efficiency of preplant versus late-season application of irrigated wheat and observed a significant increase in yield with late application. Brassard (2007) reported that grain maize aboveground biomass yields in Quebec region varies according to year (rainfall), area (soil) and nitrogen $(\mathrm{N})$ rate applied. In general, aboveground biomass increased with an increasing rate of $\mathrm{N}$ fertilizer and was more important under low rainfall amount on loam or loam-sandy soil than higher rainfall amount on loam or sandy soil. Rötter and Van Keulen (1997) reported that the response of different maize genotypes (short, medium, long, and short to medium cycle durations) to fertilization in their study varied according to different rainfall regime in the eight study zones. Finally, Keating et al. (1993) and McCown et al. (1991) suggested that farmers would benefit by adjusting cropping practices to rainfed conditions early in the season, i.e., applying fertilizers only in "good" (favorable) seasons.

The objectives of this research were (i) to determine the responses of various West-African sorghum varieties to the application of fertilizer (NPK and urea) at 
selected stages of development according to water regime (irrigated or not, different rainfall patterns), i.e., varieties*water*fertilizer interaction and (ii) to simulate them to define alternative fertilization strategies in line with climate information. It is hypothesized that (1) late fertilization would be beneficial under rainfed conditions with a well rainfall distribution after a slow beginning of the rainy season; that (2) Fadda (hybrid) is going to reply to fertilization differently from other sorghum varieties, and (3) that long-cycle varieties will benefit to late fertilization compared to short-cycle ones because a catastrophic beginning of rainy season might affect more short-cycle varieties due to their early maturity. This chapter is important because it offers the possibility to diversify fertilization strategies in areas with erratic rainfall and to minimize losses in crop production that could be related to droughts or dry spells in the season.

\section{Description of the Study Areas and Methodology}

\section{Study Area}

Three experiments were carried out during 2015-2016 growing season at "Nioro du Rip" and "Sinthiou Malème," two experimental stations of Senegalese Institute of Agricultural Research (ISRA) representing the Peanut Bassin and the Eastern Senegal agroecology. Nioro du Rip (13 $\left.{ }^{\circ} 44^{\prime} \mathrm{N} ; 15^{\circ} 46^{\prime} \mathrm{W}\right)$ and Sinthiou Malème $\left(13^{\circ} 46^{\prime}\right.$ $\left.\mathrm{N} ; 13^{\circ} 40^{\prime} \mathrm{W}\right)$ are located about $260 \mathrm{~km}$ and $440 \mathrm{~km}$ south-east of Dakar $\left(14^{\circ} 46^{\prime} \mathrm{N}\right.$; $\left.17^{\circ} 21^{\prime} \mathrm{W}\right)$, respectively.

Climate in both locations are Soudano-Sahelian with a mono modal rainfall from June to October and with maximum precipitation in August. The two locations differed mainly in total rainfall that occurred during the sorghum growing season. During this period, the total rainfall at Nioro was $1045 \mathrm{~mm}$ while it was about $525 \mathrm{~mm}$ at Sinthiou Malème. In Nioro du Rip, the rainfall has been complemented by irrigation when needed (early and late season). In Sinthiou Malème, there was no access to irrigation facilities. The mean annual maximum and minimum temperatures for Nioro du Rip and Sinthiou Malème were $35.7{ }^{\circ} \mathrm{C}$ and $20.3{ }^{\circ} \mathrm{C} ; 37^{\circ} \mathrm{C}$ and $22.2{ }^{\circ} \mathrm{C}$, respectively. Figure 1 shows temperatures, rainfall, irrigation, and timing of fertilization for the 2015-2016 growing season at the two locations.

The soils were similarly sandy at Nioro du Rip and Sinthiou Malème. For the determination of initial soil status parameters, samples were collected from $0-10 \mathrm{~cm}$, $10-20 \mathrm{~cm}$, and $20-30 \mathrm{~cm}$. The initial soil conditions are presented in Table 1, with Sinthiou Malème having a relatively richer soil.

\section{Research Methods}

\section{Experimental Design}

The experiments were conducted in a split plot design with completely randomized blocks and four replications. Treatments consisted of four different levels and timing 

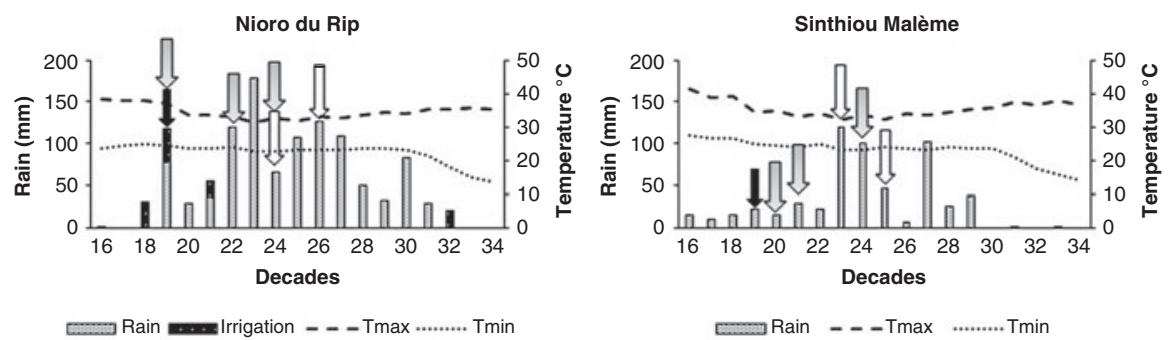

$\longrightarrow$ Sowing date $\Rightarrow$ Conventional application $\Rightarrow$ Late application

Fig. 1 Weather data, irrigation water, and fertilization dates at Nioro du Rip and Sinthiou Malème, for 621B sorghum variety (applications vary according to variety, due to the relation to growth stages)

Table 1 Initial soil conditions in Nioro du Rip and Sinthiou Malème at three different depths before sowing

\begin{tabular}{l|l|l|l|l|l|l}
\hline & \multicolumn{4}{|l|}{ Nioro du Rip } & \multicolumn{2}{l}{ Sinthiou Malème } \\
\cline { 2 - 7 } & $0-10 \mathrm{~cm}$ & $10-20 \mathrm{~cm}$ & $20-30 \mathrm{~cm}$ & $0-10 \mathrm{~cm}$ & $10-20 \mathrm{~cm}$ & $20-30 \mathrm{~cm}$ \\
\hline $\mathrm{pH}$ & 6.7 & 7.7 & 7.3 & 5.7 & 5.6 & 5.7 \\
\hline $\begin{array}{l}\text { Soil nitrate }(\mathrm{N} \\
\text { \%o })^{\mathrm{a}}\end{array}$ & 3.01 & 3.51 & 2.73 & 4.15 & 2.49 & 2.21 \\
\hline $\begin{array}{l}\text { Total carbon(C } \\
\text { \%o })^{\mathrm{b}}\end{array}$ & 0.12 & 0.14 & 0.11 & 0.41 & 0.37 & 0.29 \\
\hline $\mathrm{C} / \mathrm{N}$ & 25.85 & 24.28 & 23.83 & 10.03 & 6.69 & 7.64 \\
\hline
\end{tabular}

${ }^{a}$ Kjeldahl method

${ }^{\mathrm{b}}$ Walkley \& Black method

of fertilizers application in addition to the control (T1, no fertilizer applied). These were $150 \mathrm{~kg} / \mathrm{ha}$ of NPK (15-15-15) at emergence $+50 \mathrm{~kg} / \mathrm{ha}$ of urea (46\%) at tillering $+50 \mathrm{Kg} / \mathrm{ha}$ of urea at stem extension (T2, practice recommended by ISRA); T3 half rate of T2 applied at the same stages (i.e., at emergence, tillering, and stem extension, Fig. 1); T4 $=150 \mathrm{~kg} / \mathrm{ha}$ of NPK $+50 \mathrm{~kg} / \mathrm{ha}$ of urea at stem extension $+50 \mathrm{~kg} / \mathrm{ha}$ of urea at heading; and T5 half rate of T4 applied at the same stages (i.e., stem extension and heading, Fig. 1). These were assigned to the main plots. Four improved sorghum varieties (Fadda, IS15401, Soumba and 621B) chosen for their contrasting characteristics (phenology, architecture, response to inputs) were assigned to the subplots. Each subplot consisted of five rows of $6.8 \mathrm{~m}$ long with and an interrow spacing of $0.8 \mathrm{~m}$. The inter-hole spacing was $0.4 \mathrm{~m}$. Six seeds per hole were sown and the final plant populations were 62,500 plants/ha.

Experiments were conducted under rainfed and irrigated conditions at Nioro du Rip. Irrigated crops were irrigated four times according to dry spells (5-10 days without rainfall in addition to the visual appearance of plants) with a total of about $110 \mathrm{~mm}$ of water (Fig. 1). It was under rainfed conditions at Sinthiou Malème (because of lack of irrigation facilities). After emergence, the cultural operations 
like weeding, control of pest, and abutment were done as and when necessary for better growth and development of sorghum plants.

\section{Data Collection}

Development and growth parameters: Four plants from two center rows were randomly selected and development parameters including leaf number ( $\mathrm{Nb}$. Leaf), plant height $(\mathrm{PH})$ were monitored every 15 days from tillering to flowering. Leaf area index (LAI) and aboveground biomass were measured from four hills of three center rows for each subplot. Data presented in this chapter were recorded at flowering for $\mathrm{Nb}$. Leaf, $\mathrm{PH}$, and LAI and at stem extension for biomass before late application (BBLA) and at maturity for biomass after late fertilizer application (BALA).

Yield and biomass: At maturity, 12 hills from the 3 center rows of each subplot were harvested for measuring grain yield and aboveground biomass. Plant material (grains and biomass) was dried first under greenhouse during 2 weeks and in an oven at $65{ }^{\circ} \mathrm{C}$ for $24 \mathrm{~h}$. Oven dry weight of the samples was converted to dry matter per ha. To evaluate fertilizers treatment especially plants response to late fertilization, a response index (RI) and a harvest index were calculated as follow:

$$
\mathrm{RI}=(\mathrm{Yij} / \mathrm{Y} 2 \mathrm{j})
$$

where Yij grain yield with ith fertilization treatment and $j$ the variety and $Y 2 j$ being the yield for T2 (considered as reference fertilization treatment).

$$
\mathrm{HI}=\mathrm{Yij} / \mathrm{YBij}
$$

where Yij $=$ grain yield and $\mathrm{YB}=$ aboveground biomass yield.

Only harvest data were presented for Sinthiou Malème because growth parameters were not recorded. For the remainder of the chapter, the terms experiment, fertilizer, and variety will be designated by $\mathrm{W}$ (meaning water), $\mathrm{N}$ (meaning nitrogen), and $\mathrm{G}$ (meaning genotype), respectively.

Modeling: Calibration was carried out in the CSM-CERES-Sorghum model of Decision Support System for Agrotechnology Transfer (DSSAT) (Jones et al. 2003) aiming at correctly simulating crop cycles duration and grain yields for Fadda and IS15401 under all treatments. This is a first step to assess model performance in order to define fertilization strategies according to climate information.

\section{Data Analysis}

Statistical analyses were performed using R software (R Core Team 2017). First, the statistical analysis was focused on data from each experiment to evaluate the effect of fertilization strategies per site $\left(\mathrm{G}^{*} \mathrm{~W}\right.$ and $\left.\mathrm{G}^{*} \mathrm{~N}\right)$. Second, all the data were pooled to assess the effect of total water received on fertilization strategies according to the varieties over experiments $\left(\mathrm{G}^{*} \mathrm{~W}^{*} \mathrm{~N}\right)$. Analysis of variance (ANOVA) of the measured parameters was performed and the treatment means were compared using least significant difference (LSD) at the 5\% level of probability. 
Table 2 Effect of fertilization and varieties on number of leaf, height, leaf area index, biomass before and after late application according to experimental conditions

\begin{tabular}{|c|c|c|c|c|c|c|}
\hline \multirow[b]{2}{*}{$\begin{array}{l}\text { Experiments } \\
(\mathrm{W})^{\mathrm{a}}\end{array}$} & \multirow[b]{2}{*}{ Source } & \multicolumn{2}{|c|}{$\begin{array}{l}\text { Development } \\
\text { parameters }\end{array}$} & \multicolumn{3}{|c|}{ Growth parameters } \\
\hline & & $\begin{array}{l}\text { Nb. Leaf } \\
(\mathrm{P}>\mathrm{F})\end{array}$ & $\begin{array}{l}\mathrm{PH} \\
(\mathrm{P}>\mathrm{F})\end{array}$ & $\begin{array}{l}\text { LAI } \\
(\mathrm{P}>\mathrm{F})\end{array}$ & $\begin{array}{l}\text { BBLA } \\
(\mathrm{P}>\mathrm{F})\end{array}$ & $\begin{array}{l}\text { BALA } \\
(\mathrm{P}>\mathrm{F})\end{array}$ \\
\hline \multirow{3}{*}{$\begin{array}{l}\text { Nioro Du } \\
\text { Rip } \\
\text { Rainfed }\end{array}$} & $\begin{array}{l}\text { Varieties } \\
\text { (G) }\end{array}$ & $<0.0001$ & $\begin{array}{l}< \\
0.0001\end{array}$ & $\begin{array}{l}< \\
0.0001\end{array}$ & 0.027 & $<0.0001$ \\
\hline & $\begin{array}{l}\text { Fertilization } \\
\text { (N) }\end{array}$ & 0.013 & $\begin{array}{l}< \\
0.0001\end{array}$ & 0.04 & 0.011 & 0.067 \\
\hline & $\mathbf{N} * \mathbf{G}$ & 0.534 & 0.051 & $\begin{array}{l}< \\
0.0001\end{array}$ & 0.587 & 0.007 \\
\hline \multirow{3}{*}{$\begin{array}{l}\text { Nioro Du } \\
\text { Rip } \\
\text { Irrigated }\end{array}$} & G & $<0.0001$ & $\begin{array}{l}< \\
0.0001\end{array}$ & 0.0001 & 0.041 & $<0.0001$ \\
\hline & $\mathbf{N}$ & 0.047 & $<0.0001$ & 0.524 & 0.13 & 0.038 \\
\hline & $N * G$ & $<0.008$ & 0.048 & 0.832 & 0.897 & 0.479 \\
\hline
\end{tabular}

$G$ varieties, $N$ fertilization, $N^{*} G$ interaction between fertilization and varieties, $N b$. Leaf number of leaf, $P H$ plant height, $L A I$ leaf area index, BBLA biomass before late application, BALA biomass after late application

${ }^{\mathrm{a}}$ Data at Sinthiou Malème are not presented because not measured

\section{Results and Discussion}

\section{Development and Growth Parameters}

\section{Parameters by Environment}

Table 2 shows results of the analysis of variance (ANOVA) for development (leaf number, plant height, leaf area index) and growth (biomass before and after late fertilizer application) parameters. The ANOVA showed that, no matter the environment, all parameters are significantly different due to the variety. Guinea varieties (Fadda and IS15401) gave the greatest growth parameters. 621B (caudatum) produced the lowest.

Regarding fertilization, $\mathrm{Nb}$. Leaf and $\mathrm{PH}$ were affected by fertilization irrespective of the environment, while LAI and BBLA were affected significantly by fertilization only under rainfed conditions. Conversely, BALA was only affected by fertilization treatments under irrigation. $\mathrm{G}^{*} \mathrm{~N}$ interactions affected significantly LAI under rainfed conditions and $\mathrm{Nb}$. leaf and $\mathrm{PH}$ under irrigated ones.

Considering each environment, ANOVA indicated significant effects of $\mathrm{N}$ on BBLA under rainfed conditions (Table 2). Plants were stressed experiencing lower biomass under T4, T5, and T1 (882, 685, and $645 \mathrm{~kg} /$ ha, respectively). However, BALA was affected only under irrigated conditions with lower dry matter under $\mathrm{T} 1$ and T4 (5941 and $5031 \mathrm{~kg} / \mathrm{ha}$, respectively). These results indicate that applying reasonable amount of fertilizers later in the season (T5) gives better response, with the plant recovering from water (and nitrogen) stress. 


\section{All Environments Included}

Irrespective of the environment, the application of $150 \mathrm{~kg} / \mathrm{ha}$ of NPK at emergence, $50 \mathrm{~kg} / \mathrm{ha}$ of urea at tillering, and $50 \mathrm{~kg} / \mathrm{ha}$ of urea at stem extension (T2) produced more leaves (27.78) than the control with no fertilizer (26.47). This highest leaf number is similar to the one produced under T3, T4, and T5. Furthermore, leaf number varied significantly across experiments. $\mathrm{Nb}$. leaf and LAI were neither affected by experiments $\times$ fertilization $\left(\mathrm{W}^{*} \mathrm{~N}\right)$, nor by experiments $\times$ variety $\left(\mathrm{W}^{*} \mathrm{G}\right)$, nor by variety $\times$ fertilization $\left(\mathrm{G}^{*} \mathrm{~N}\right)$, nor by experiments $\times$ fertilization $\times$ varieties $\left(\mathrm{G}^{*} \mathrm{~W}^{*} \mathrm{~N}\right)$ interactions.

There was a significant interaction between experiments and fertilization treatments $\left(W^{*} N\right)$ and between variety and fertilization $\left(G^{*} N\right)$ for plant height. $G^{*} W^{*} N$ interactions for this parameter were not significant. Plant height affected by $\mathrm{W}^{*} \mathrm{~N}$ interaction is presented in Fig. 2. Plant height varied from 2.5 to $1.5 \mathrm{~m}$ with an average mean of $2.0 \mathrm{~m}$. High plant size were obtained under T2 in both rainfed and irrigated conditions. Plant height under T4 and T5 was statistically similar to plant height with application of half amount of T2 (T3) in both conditions except T5 under rainfed experiment. Moreover, application of $150 \mathrm{~kg} / \mathrm{ha}$ of NPK $+50 \mathrm{~kg} / \mathrm{ha}$ of urea at stem extension $+50 \mathrm{~kg} / \mathrm{ha}$ of urea at heading (T4) and application of its half amount at same stages (T5) in rainfed condition gave similar plant height compared to T4 and $\mathrm{T} 5$ under irrigated conditions.

BBLA was not affected by $\mathrm{W}^{*} \mathrm{~N}$ interactions while BALA was (Table 3). Dry matter under $\mathrm{T} 4$ in rainfed conditions was higher than $\mathrm{T} 4$ under well-watered condition. However, dry matter was lower with T5 under rainfed conditions compared to T5 in irrigated conditions (Fig. 3). As most of the irrigations were applied before late application to avoid dry spells recorded in the beginning of growing season, varieties better response with $\mathrm{T} 4$ under rainfed conditions suggested that fertilizer application late-in-season is suitable when rainfall seems to be good after a catastrophic beginning, while in favorable conditions (i.e., irrigated), T5 is recommended rather than $\mathrm{T} 4$.

\section{Yield, Plant Biomass, Harvest Index, and Response Index}

\section{Yield, Biomass, Harvest Index, and Response Index by Environment}

Table 4 shows the summary of ANOVA for grain yield, plant biomass at harvest, harvest index (HI), and response to fertilization index (RI) for the different fertilization and variety treatments. Considering each experiment, variety affected yield, biomass, HI and RI except for yield, and RI at Sinthiou. The fertilization affected significantly yield except at Sinthiou. It affected also biomass and response index in Nioro irrigated and Sinthiou rainfed experiments, respectively.

The splitting pattern of fertilization $\times$ variety interactions varied according to environments. Sinthiou Malème and Nioro du Rip (irrigated) experiments which received the lowest and greatest water, respectively were affected significantly by 


\section{Plant height}

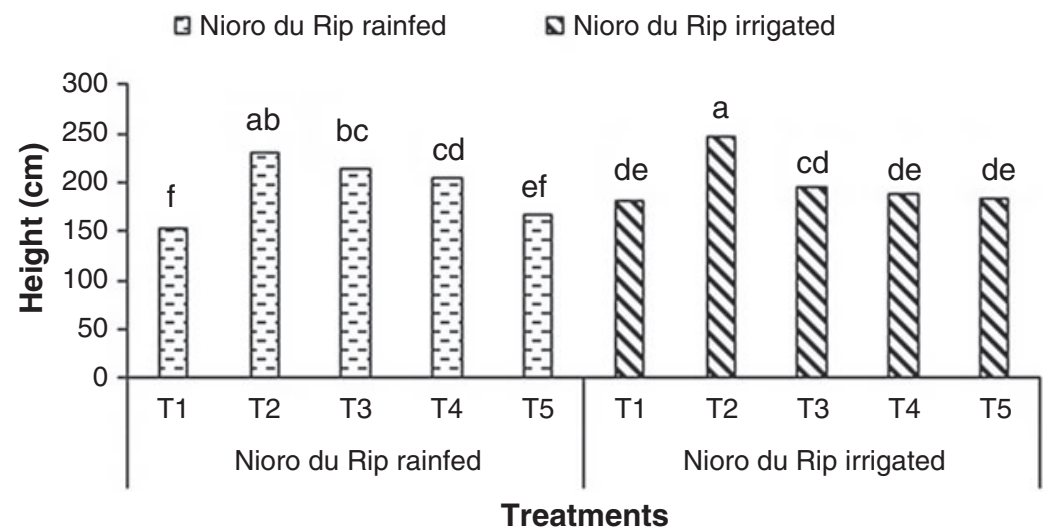

Fig. 2 Interaction between experiment (total water received) and fertilization on plant height. Values are means of four replications. Column followed by same letters are not significantly different at $\mathrm{P}<0.05$. T1 = no fertilizer; $\mathrm{T} 2=150 \mathrm{~kg} / \mathrm{ha}$ of NPK (15-15-15) at emergence $+50 \mathrm{~kg} / \mathrm{ha}$ of urea $(46 \%)$ at tillering $+50 \mathrm{Kg} / \mathrm{ha}$ of urea at stem extension; $\mathrm{T} 3=75 \mathrm{~kg} / \mathrm{ha}$ of NPK $(15-15-15)$ at emergence $+25 \mathrm{~kg} / \mathrm{ha}$ of urea $(46 \%)$ at tillering $+25 \mathrm{Kg} / \mathrm{ha}$ of urea at stem extension; $\mathrm{T} 4=150 \mathrm{~kg} / \mathrm{ha}$ of NPK $+50 \mathrm{~kg} / \mathrm{ha}$ of urea at stem extension $+50 \mathrm{~kg} / \mathrm{ha}$ of urea at heading; $\mathrm{T} 5=75 \mathrm{~kg} / \mathrm{ha}$ of NPK $(15-15-15)+25 \mathrm{~kg} / \mathrm{ha}$ of urea (46\%) at stem extension $+25 \mathrm{Kg} / \mathrm{ha}$ of urea at heading

Table 3 Effect of fertilization, varieties and environments on number of leaf, height, leaf area index, biomass before and after late application

\begin{tabular}{l|l|l|l|l|l|l}
\hline & \multicolumn{3}{|l|}{ Development parameters } & \multicolumn{2}{l}{ Growth parameters } \\
\cline { 3 - 7 } $\begin{array}{l}\text { Experiments } \\
\text { (W) }\end{array}$ & Source & $\begin{array}{l}\text { Nb. Leaf } \\
(\mathrm{P}>\mathrm{F})\end{array}$ & $\begin{array}{l}\text { PH } \\
(\mathrm{P}>\mathrm{F})\end{array}$ & $\begin{array}{l}\text { LAI } \\
(\mathrm{P}>\mathrm{F})\end{array}$ & $\begin{array}{l}\text { BBLA } \\
(\mathrm{P}>\mathrm{F})\end{array}$ & $\begin{array}{l}\text { BALA } \\
(\mathrm{P}>\mathrm{F})\end{array}$ \\
\hline
\end{tabular}

\section{ANOVA over experiments}

\begin{tabular}{l|l|c|c|c|c|c}
\hline & $\mathbf{G}$ & $<0.0001$ & $<0.0001$ & $<0.0001$ & 0.004 & $<0.0001$ \\
\hline $\mathbf{W}$ & $<0.0001$ & 0.527 & 0.799 & 0.002 & 0.709 \\
\hline $\mathbf{N}$ & 0.009 & $<0.0001$ & 0.146 & $<0.0001$ & $<0.0001$ \\
\hline & $\mathbf{W} \mathbf{N}$ & 0.995 & 0.001 & 0.232 & 0.249 & 0.009 \\
\hline & $\mathbf{G}^{*} \mathbf{W}$ & 0.384 & 0.737 & 0.636 & 0.587 & 0.221 \\
\hline & $\mathbf{G}^{*} \mathbf{N}$ & 0.091 & 0.041 & 0.053 & 0.964 & 0.466 \\
\hline & $\mathbf{G}^{*} \mathbf{W} \mathbf{N}$ & 0.237 & 0.08 & 0.068 & 0.79 & 0.372 \\
\hline
\end{tabular}

$G$ varieties, $W$ environment, $N$ fertilization, $W^{*} N, G^{*} W, G^{*} N$ and $G^{*} W^{*} N$ interactions between environment and fertilization; varieties and environment; varieties and fertilization; varieties, environment and fertilization, respectively, $N b$. Leaf number of leaf, $P H$ plant height, $L A I$ leaf area index, $B B L A$ biomass before late application, $B A L A$ biomass after late application 
Plant biomass before and after fertilizers late application

๑BBLA 중 BALA

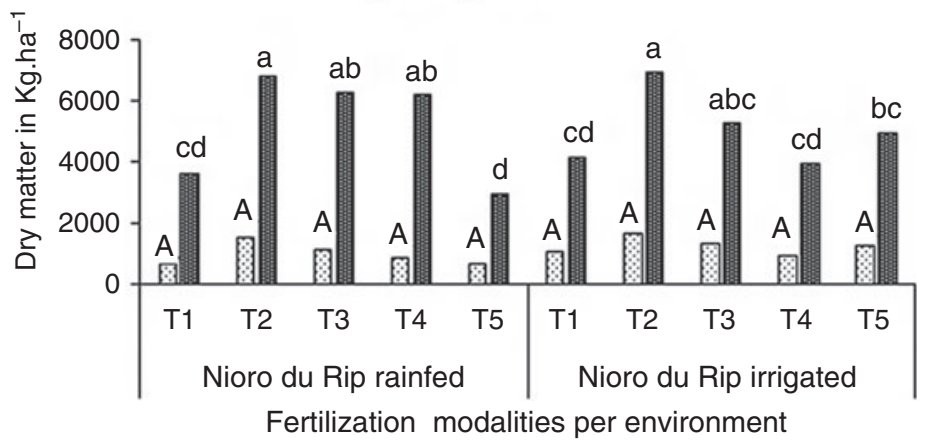

Fig. 3 Interaction between total water received and fertilization on plant biomass before and after late application. Values are means of four replications. Upper case compares BBLA columns and low case comparison between BALA columns. Column followed by same letters are not significantly different at $\mathrm{P}<0.05$. T1 $=$ no fertilizer; $\mathrm{T} 2=150 \mathrm{~kg} / \mathrm{ha}$ of NPK $(15-15-15)$ at emergence $+50 \mathrm{~kg} / \mathrm{ha}$ of urea $(46 \%)$ at tillering $+50 \mathrm{Kg} / \mathrm{ha}$ of urea at stem extension; T3 $=75 \mathrm{~kg} / \mathrm{ha}$ of NPK $(15-15-15)$ at emergence $+25 \mathrm{~kg} / \mathrm{ha}$ of urea $(46 \%)$ at tillering $+25 \mathrm{Kg} / \mathrm{ha}$ of urea at stem extension; $\mathrm{T} 4=150 \mathrm{~kg} / \mathrm{ha}$ of NPK $+50 \mathrm{~kg} / \mathrm{ha}$ of urea at stem extension $+50 \mathrm{~kg} / \mathrm{ha}$ of urea at heading; $\mathrm{T} 5=75 \mathrm{~kg} / \mathrm{ha}$ of NPK $(15-15-15)+25 \mathrm{~kg} / \mathrm{ha}$ of urea (46\%) at stem extension $+25 \mathrm{Kg} / \mathrm{ha}$ of urea at heading

Table 4 Effect of fertilization and varieties on yield, biomass, harvest index, and response index according to the environments

\begin{tabular}{l|l|l|c|c}
\hline Source & Yield $(\mathrm{P}>\mathrm{F})$ & Biomass $(\mathrm{P}>\mathrm{F})$ & $\mathrm{HI}(\mathrm{P}>\mathrm{F})$ & RI $(\mathrm{P}>\mathrm{F})$ \\
\hline \multicolumn{4}{l}{ Nioro du rip Rainfed experiment } \\
\hline $\mathrm{G}$ & $<0.0001$ & $<0.0001$ & $<0.0001$ & $<0.0001$ \\
\hline $\mathrm{N}$ & 0.04 & 0.067 & 0.699 & 0.129 \\
\hline $\mathrm{G} * \mathrm{~N}$ & 0.257 & 0.007 & 0.863 & 0.231 \\
\hline
\end{tabular}

Nioro du rip irrigated experiment

\begin{tabular}{l|c|c|c|l}
\hline $\mathrm{G}$ & $<0.0001$ & $<0.0001$ & $<0.0001$ & 0.026 \\
\hline $\mathrm{N}$ & 0.033 & 0.038 & 0.603 & 0.196 \\
\hline $\mathrm{G}^{*} \mathrm{~N}$ & 0.004 & 0.479 & 0.245 & 0.7
\end{tabular}

Sinthiou Malème rainfed experiment

\begin{tabular}{l|l|l|l|l}
\hline $\mathrm{G}$ & 0.099 & $<0.0001$ & 0.003 & 0.206 \\
\hline $\mathrm{N}$ & 0.58 & 0.79 & 0.817 & 0.017 \\
\hline $\mathrm{G}^{*} \mathrm{~N}$ & 0.026 & 0.998 & 0.501 & 0.86 \\
\hline
\end{tabular}

$G$ varieties, $N$ fertilization, $G^{*} N$ interactions between varieties and fertilization, $H I$ harvest index, $R I$ response index

$\mathrm{G} \times \mathrm{N}$ interactions (Table 4) for yield, while the rainfed Nioro du Rip experiment was significantly affected by $\mathrm{G}^{*} \mathrm{~N}$ for biomass.

Figure 4 displays grain yield for the fertilization $\times$ variety $\left(\mathrm{N}^{*} \mathrm{G}\right)$ interactions at Nioro du Rip in irrigated conditions. It varied from 2111 to $261 \mathrm{~kg}$ per hectare with a 


\section{Grain Yield Nioro du Rip irrigated}

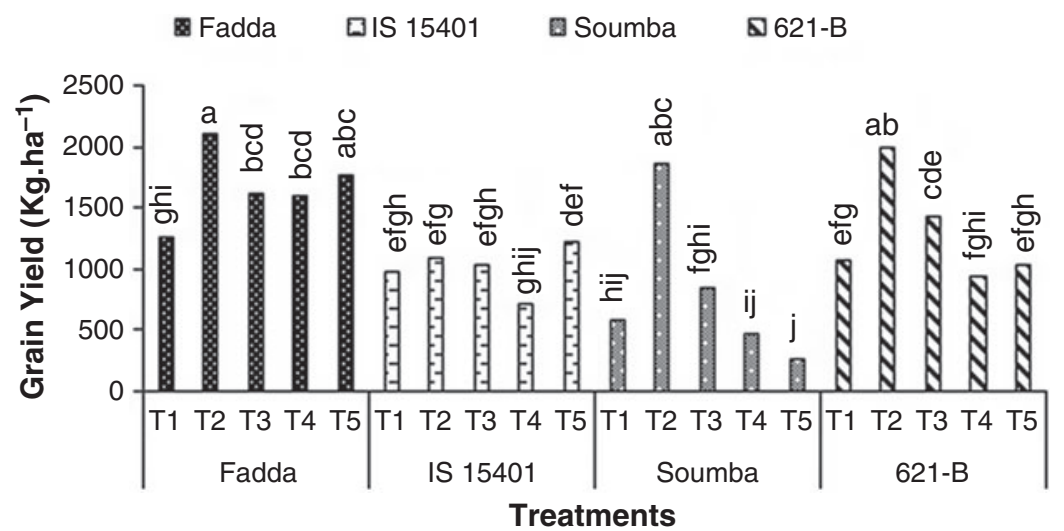

Fig. 4 Grain yield as affected by fertilizers treatments on four sorghum varieties at Nioro du Rip under rainfed with irrigation. Values are means of four replications. T1 $=$ no fertilizer; T2 $=150 \mathrm{~kg}$ / ha of NPK (15-15-15) at emergence $+50 \mathrm{~kg} / \mathrm{ha}$ of urea (46\%) at tillering $+50 \mathrm{Kg} / \mathrm{ha}$ of urea at stem extension; T3 $=75 \mathrm{~kg} / \mathrm{ha}$ of NPK $(15-15-15)$ at emergence $+25 \mathrm{~kg} / \mathrm{ha}$ of urea $(46 \%)$ at tillering +25 $\mathrm{Kg} / \mathrm{ha}$ of urea at stem extension; T4 $=150 \mathrm{~kg} / \mathrm{ha}$ of NPK $+50 \mathrm{~kg} / \mathrm{ha}$ of urea at stem extension $+50 \mathrm{~kg} / \mathrm{ha}$ of urea at heading; T5 $=75 \mathrm{~kg} / \mathrm{ha}$ of NPK $(15-15-15)+25 \mathrm{~kg} / \mathrm{ha}$ of urea (46\%) at stem extension $+25 \mathrm{Kg} / \mathrm{ha}$ of urea at heading

mean value of $1195 \mathrm{~kg} / \mathrm{ha}$. Significantly higher grain yield was produced under T2 $\times$ Fadda, T5 $\times$ Fadda, T2 $\times$ Soumba, and T $\times 621 \mathrm{~B}$ treatments as compared to T4 $\times$ Soumba and T5 $\times$ Soumba treatments, giving the lowest yield. The grain yield reduction under the T4 and T5 $\times$ Soumba treatments was $78 \%$ and $88 \%$, respectively, compared to T2 $\times$ Fadda treatment which produced the highest grain yield. Intermediate grain yield was obtained with T3 and T4 for Fadda, T5 for IS15401, and with $\mathrm{T} 3$ for $621 \mathrm{~B}$. Late application gave better grain yield with Fadda under T4 and T5 treatments and with IS15401 under T5. The late application under irrigated conditions seems to give better results with only long cycle varieties. Moreover, this result indicates that late application with low fertilizer rate is more suitable than the total amount applied when we have optimal water conditions.

Grain yield at Sinthiou Malème is represented in Fig. 5. Yield varied from 1670 to $267 \mathrm{~kg}$ per hectare with an average value of $888 \mathrm{~kg} / \mathrm{ha}$. The grain produced was higher under T2 $\times$ Fadda, T3 $\times$ Fadda, T4 $\times$ IS15401, T5 $\times$ IS15401, T4 $\times 621 \mathrm{~B}$, while the lowest yield was obtained with $\mathrm{T} 1 \times$ Fadda. The grain yield reduction under the T1 $\times$ Fadda treatment was $84 \%$ compared to the T2 treatment for Fadda (highest grain producing treatment). In contrast, T1 $\times$ IS15401 was also high (996 kg/ha). The application of fertilizer late-in-season (T4 and T5) increased grain yield for IS 15401 and $621 \mathrm{~B}$ compared to the actual recommendation in cereal fertilization in Senegal (T2). This result suggests that late application is beneficial for both varieties cycles, under low rainfed conditions. 


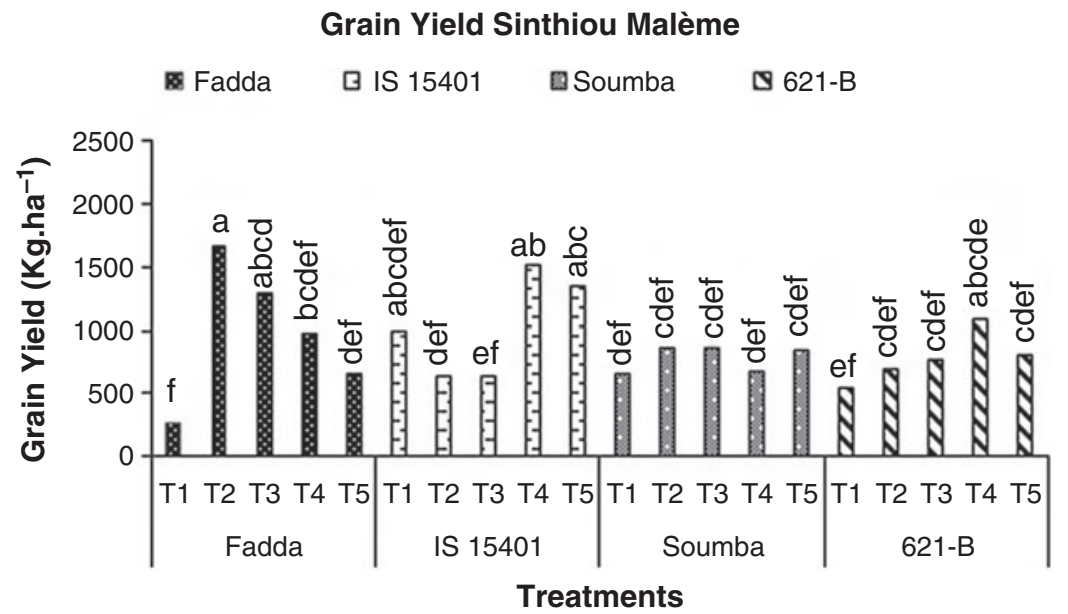

Fig. 5 Grain yield as affected by fertilizers treatments on four sorghum varieties at Sinthiou Malème. Values are means of four replications. T1 $=$ no fertilizer; $\mathrm{T} 2=150 \mathrm{~kg} / \mathrm{ha}$ of NPK $(15-15-15)$ at emergence $+50 \mathrm{~kg} / \mathrm{ha}$ of urea $(46 \%)$ at tillering $+50 \mathrm{Kg} / \mathrm{ha}$ of urea at stem extension; $\mathrm{T} 3=75 \mathrm{~kg} / \mathrm{ha}$ of NPK (15-15-15) at emergence $+25 \mathrm{~kg} / \mathrm{ha}$ of urea $(46 \%)$ at tillering $+25 \mathrm{Kg} / \mathrm{ha}$ of urea at stem extension; T4 $=150 \mathrm{~kg} / \mathrm{ha}$ of NPK $+50 \mathrm{~kg} / \mathrm{ha}$ of urea at stem extension $+50 \mathrm{~kg} / \mathrm{ha}$ of urea at heading; T5 $=75 \mathrm{~kg} / \mathrm{ha}$ of NPK $(15-15-15)+25 \mathrm{~kg} / \mathrm{ha}$ of urea $(46 \%)$ at stem extension +25 $\mathrm{Kg} / \mathrm{ha}$ of urea at heading

$\mathrm{G}^{*} \mathrm{~N}$ interactions were significant for two experiments over three. Probably, rainfall distribution in rainfed conditions at Nioro du Rip induced water stress. Sometimes, there was dry spells of 8-9 days up to 10 days before recording rainfall again. Water deficit might reduce nitrogen effect and jeopardize grain filling. The rate and distribution of fertilizer (NPK and urea) considerably affected the grain yield with high production under T2, T4, and T5. The better grain yield recorded with the late fertilizer application treatments (T4 and T5 for some varieties in both conditions) might be due to high nitrogen uptake and water availability (sufficient water uptake for grain filling). The results are consistent with the findings of Amiri et al. (2014). These authors studying different levels and time of nitrogen application on grain sorghum in Iran reported that the highest sorghum grain yield was obtained with $25 \%$ of $\mathrm{N}$ applied at planting stage $+50 \% \mathrm{~N}$ at stem elongation $+25 \% \mathrm{~N}$ at reproductive stage. On the other hand, Blandino et al. (2015) reported granular $\mathrm{N}$ soil fertilization at the beginning of heading and foliar liquid $\mathrm{N}$ fertilization at anthesis did not influence yield of common wheat but these late-season $\mathrm{N}$ fertilizations increased grain yield of durum wheat. However, Fageria and Baligar (1999) observed low grain yield on lowland rice with two late-season $\mathrm{N}$ fertilization defined as (i) one-third $\mathrm{N}$ applied at planting + one-third at panicle initiation + one-third at flowering and (ii) the application of zero $\mathrm{N}$ at sowing + one-third $\mathrm{N}$ at the initiation of tillering + one-third $\mathrm{N}$ at booting + one-third $\mathrm{N}$ at flowering. 
Table 5 Effect of fertilization, varieties and environments on yield, biomass, harvest index, and response index

\begin{tabular}{|c|c|c|c|c|}
\hline Source & Yield $(\mathrm{P}>\mathrm{F})$ & Biomass $(\mathrm{P}>\mathrm{F})$ & $\mathrm{HI}(\mathrm{P}>\mathrm{F})$ & $\mathrm{RI}(\mathrm{P}>\mathrm{F})$ \\
\hline \multicolumn{5}{|c|}{ ANOVA over experiments } \\
\hline $\mathrm{G}$ & $<0.0001$ & $<0.0001$ & $<0.0001$ & 0.403 \\
\hline W & 0.0007 & 0.281 & 0.001 & 0.002 \\
\hline $\mathrm{N}$ & $<0.0001$ & $<0.0001$ & 0.817 & 0.749 \\
\hline $\mathrm{W}^{*} \mathrm{~N}$ & 0.045 & 0.002 & 0.929 & 0.476 \\
\hline $\mathrm{G}^{*} \mathrm{~W}$ & 0.001 & 0.084 & 0.079 & 0.056 \\
\hline $\mathrm{G}^{*} \mathrm{~N}$ & 0.011 & 0.681 & 0.622 & 0.922 \\
\hline $\mathrm{G}^{*} \mathrm{~W}^{*} \mathrm{~N}$ & 0.784 & 0.828 & 0.592 & 0.884 \\
\hline
\end{tabular}

$G$ varieties, $W$ environment, $N$ fertilization, $W^{*} N, G^{*} W, G^{*} N$, and $G^{*} W^{*} N$ interactions between environment and fertilization; varieties and environment; varieties and fertilization; varieties, environment, and fertilization, respectively, $H I$ harvest index, $R I$ response index

\section{All Environments Included}

Irrespective of the environment, the fertilization treatment affected significantly grain yield and plant biomass whereas variety affected significantly grain yield, biomass, and HI. Experimental conditions affected grain yield, HI, and RI significantly over experiments. However, neither harvest index nor response to fertilization index varied according to fertilization. $\mathrm{W}^{*} \mathrm{G}$ interactions affected only yield. Experiment $\times$ fertilization $\times$ variety $\left(\mathrm{G}^{*} \mathrm{~W}^{*} \mathrm{~N}\right)$ interactions neither affected grain yield nor plant biomass, harvest index, and response to fertilization index (Table 5). Nonsignificant $\mathrm{G}^{*} \mathrm{~W}^{*} \mathrm{~N}$ interactions indicates that varieties behave similarly in the three experiments.

The interactive effect of fertilizers rate and distribution and total water received (experiments) on HI and RI was not significant confirming the potential of late application. The experiment $\times$ fertilization $\left(\mathrm{W}^{*} \mathrm{~N}\right)$ interactions affected yield and biomass (Fig. 6). T2 irrigated gave the highest grain yield. Better yield with late application were obtained with T5 irrigated and T4 rainfed at Sinthiou. The greatest dry matter was obtained with T2 irrigated, T2, T3, and T4 Nioro rainfed.

Plant biomass at harvest varied according to fertilizers rate and distribution and environment by fertilization interactions. Comparison of means via least significant difference (LSD) showed that the highest dry matter yield $(6031 \mathrm{Kg} / \mathrm{ha})$ belonged to $\mathrm{T} 2$ and the lowest (3739 kg/ha) belonged to the treatment with no fertilizer (T1). T4 and T5 gave identical dry matter but less than T2 one. As nutrients were early available to plant under $\mathrm{T} 2$, the $\mathrm{N}$ uptake increased and more assimilates were produced.

Grain yield over experiments is significantly affected by $\mathrm{G} \times \mathrm{N}$ interactions (Table 5, Fig. 7). The highest grain yield was produced under application on Fadda with $150 \mathrm{~kg}$ of NPK $15-15-15$ per hectare at emergence and $100 \mathrm{~kg}$ of urea in two equal split at tillering and stem elongation (T2) and the lowest under application of $75 \mathrm{~kg} / \mathrm{ha}$ of NPK $15-15-15+25 \mathrm{~kg}$ of urea at stem extension and $25 \mathrm{~kg} / \mathrm{ha}$ of urea at heading (T5) for Soumba. The grain yield reduction under the T5 $\times$ Soumba treatments was $75 \%$ as compared to the $\mathrm{T} 2 \times$ Fadda treatment which produced the 
a

\section{Grain yields per environment}

घ Nioro du Rip rainfed $\square$ Nioro du Rip irrigated $\square$ Sinthiou Malème rainfed

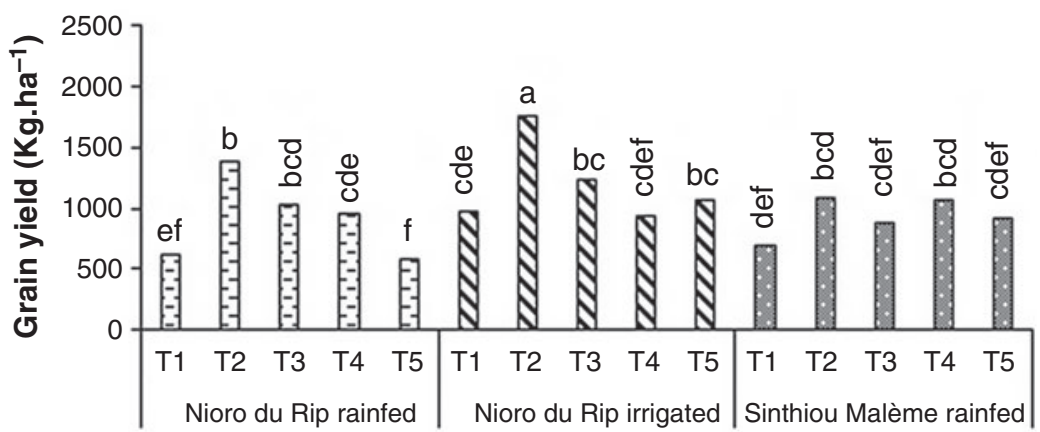

Treatments per environment

\section{b Biomass at harvest per environment}

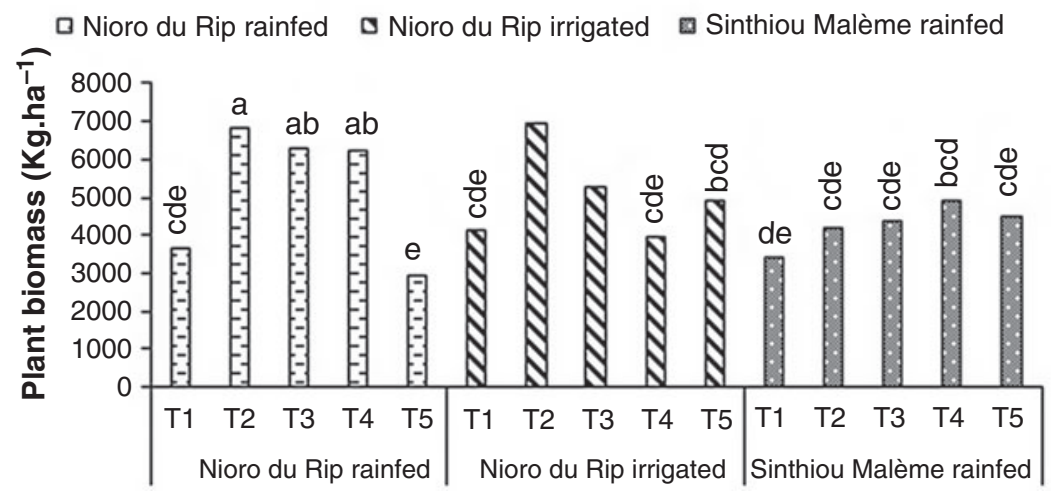

Treatments per environment

Fig. 6 Grain yield and biomass as affected by fertilization $\times$ experiment interaction experiments. Values are means of four replications. T1 = no fertilizer; T2 $=150 \mathrm{~kg} / \mathrm{ha}$ of NPK (15-15-15) at emergence $+50 \mathrm{~kg} / \mathrm{ha}$ of urea $(46 \%)$ at tillering $+50 \mathrm{Kg} / \mathrm{ha}$ of urea at stem extension; T3 $=75 \mathrm{~kg} / \mathrm{ha}$ of NPK (15-15-15) at emergence $+25 \mathrm{~kg} / \mathrm{ha}$ of urea $(46 \%)$ at tillering $+25 \mathrm{Kg} / \mathrm{ha}$ of urea at stem extension; T4 $=150 \mathrm{~kg} / \mathrm{ha}$ of NPK $+50 \mathrm{~kg} / \mathrm{ha}$ of urea at stem extension $+50 \mathrm{~kg} / \mathrm{ha}$ of urea at heading; T5 $=75 \mathrm{~kg} / \mathrm{ha}$ of NPK $(15-15-15)+25 \mathrm{~kg} / \mathrm{ha}$ of urea $(46 \%)$ at stem extension $+25 \mathrm{Kg} / \mathrm{ha}$ of urea at heading

highest grain yield. Similar and intermediate grain yields were obtained with T2 for Soumba and 621B, T3 for Fadda, and 621B and T4 for Fadda. Late fertilizer applications (T4 and T5) gave better grain yields with IS15401 and Fadda. Variety replied differently to fertilization. Fadda showed a higher grain yield than IS15401, Soumba and $621 \mathrm{~B}$ with $1403,842,770$, and $1027 \mathrm{~kg} \cdot \mathrm{ha}^{-1}$, respectively. These results confirmed the second and third assumptions, that Fadda is going to reply to 


\section{Grain Yield over experiments}

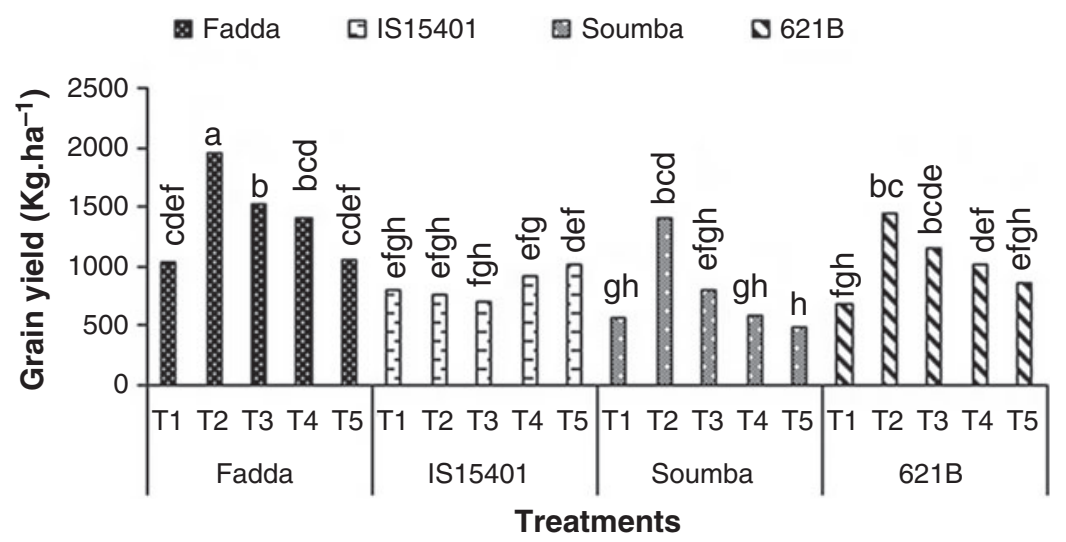

Fig. 7 Grain yield as affected by fertilization $\mathrm{x}$ variety interaction over experiments. Values are means of four replications. T1 $=$ no fertilizer; T2 $=150 \mathrm{~kg} / \mathrm{ha}$ of NPK $(15-15-15)$ at emergence $+50 \mathrm{~kg} / \mathrm{ha}$ of urea $(46 \%)$ at tillering $+50 \mathrm{Kg} / \mathrm{ha}$ of urea at stem extension; $\mathrm{T} 3=75 \mathrm{~kg} / \mathrm{ha}$ of NPK $(15-15-15)$ at emergence $+25 \mathrm{~kg} / \mathrm{ha}$ of urea ( $46 \%)$ at tillering $+25 \mathrm{Kg} / \mathrm{ha}$ of urea at stem extension; $\mathrm{T} 4=150 \mathrm{~kg} / \mathrm{ha}$ of NPK $+50 \mathrm{~kg} / \mathrm{ha}$ of urea at stem extension $+50 \mathrm{~kg} / \mathrm{ha}$ of urea at heading; $\mathrm{T} 5=75 \mathrm{~kg} / \mathrm{ha}$ of NPK $(15-15-15)+25 \mathrm{~kg} / \mathrm{ha}$ of urea $(46 \%)$ at stem extension $+25 \mathrm{Kg} / \mathrm{ha}$ of urea at heading

fertilization differently from other varieties and long-cycle varieties will benefit to late fertilization compared to short-cycle ones.

\section{Grain Yield Simulations}

Results presented here (Fig. 8) are the first simulations on Fadda and IS15401 at the two sites. Simulations gave good results for T1, T2, and T3 but overestimated yields for T4 and T5. DSSAT gives the same results for T2 and T4 and for T3 and T5. Hence, the delay in fertilizer application is not yet simulated and the model needs to be improved.

Results suggest the need for crop model improvements to better simulate the effect of late-season fertilization on grain yield and thus help to define fertilization strategies based on climate information.

\section{Conclusion}

In this research, the effect of different levels of fertilizers and its split application (late-season application) based on climate information (rainfall distribution) was investigated. The results showed that rate and distribution of fertilizers affected significantly plant height, leaf number, biomass, and grain yield. However, the response index was not statistically different when comparing T2 (recommended 

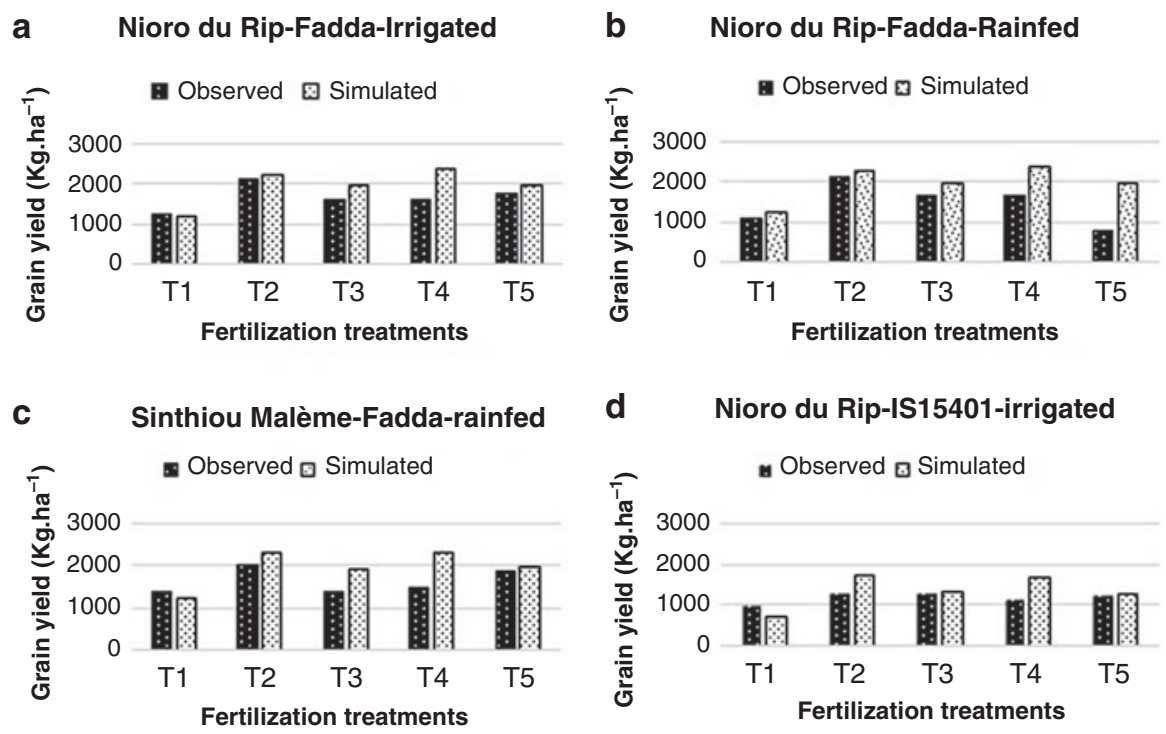

Fig. 8 Comparison of observed grain yield and yield simulated with CERES sorghum for Fadda and IS15401. Values of observed data are means of four replications. T1 = no fertilizer; $\mathrm{T} 2=150 \mathrm{~kg} / \mathrm{ha}$ of NPK $(15-15-15)$ at emergence $+50 \mathrm{~kg} / \mathrm{ha}$ of urea $(46 \%)$ at tillering $+50 \mathrm{Kg} / \mathrm{ha}$ of urea at stem extension; T3 $=75 \mathrm{~kg} / \mathrm{ha}$ of NPK (15-15-15) at emergence $+25 \mathrm{~kg} / \mathrm{ha}$ of urea $(46 \%)$ at tillering $+25 \mathrm{Kg} / \mathrm{ha}$ of urea at stem extension; T4 $=150 \mathrm{~kg} / \mathrm{ha}$ of NPK $+50 \mathrm{~kg} / \mathrm{ha}$ of urea at stem extension $+50 \mathrm{~kg} / \mathrm{ha}$ of urea at heading; T5 $=75 \mathrm{~kg} / \mathrm{ha}$ of NPK $(15-15-15)+25 \mathrm{~kg} / \mathrm{ha}$ of urea $(46 \%)$ at stem extension $+25 \mathrm{Kg} / \mathrm{ha}$ of urea at heading

practice) to other fertilization strategies. Variety*nitrogen $\left(\mathrm{G}^{*} \mathrm{~N}\right)$ interactions effects on crop growth and development depend on experimental conditions. Results revealed that under rainfed conditions a late application of $100 \%$ of the fertilizers enables the plant biomass, initially stressed, to get back to the same level as if the application was done earlier. However, under irrigated conditions we concluded that T5 was better than T4, for plant biomass as well as for grain yield. Fertilizers late application in-season was beneficial in rainfed condition and Fadda, a hybrid, replied to fertilization differently from other varieties. Both short- and long-cycle varieties replied to the late application. Varieties behaved similarly no matter water and fertilizer received. The findings about a single year study and three water regime models would be more relevant with more water regime patterns at different soil texture site in long-term study and this will be presented at the conference. Furthermore, the crop model CERES-sorghum seems not to take into account the effects of late fertilizers application. Model improvements will be investigated to broaden decision-making tools that can help to face climate change effects by developing fertilizers recommendation based on rainfall patterns. Once the model is improved, it will define fertilization strategies for sorghum based on rainfall forecasts in Sahel conditions, essential to improve crops production and to maintain resilience in Africa. 


\section{References}

Almodares A, Hadi MR, Ranjbar M, Taheri R (2007) The effect of nitrogen treatments, cultivars and harvest stages on stalk yield and sugar content in sweet sorghum. Asian J Plant Sci 6:423-426. https://doi.org/10.3923/ajps.2007.423.426

Amiri M, Mojaddam M, Shokouhfar A, Bakhtiarinejad N (2014) The effect of different levels and time of nitrogen application on grain yield, some physiological traits and nitrogen use efficacy in grain sorghum. Indian J Fundam Appl Life Sci 4:223-227

Bezançon G, Renno J-F, Kumar KA (1997) Le mil. In: Hamon S (ed) L'amélioration des plantes tropicales. CIRAD/ORSTOM, Paris, pp 457-482

Blandino M, Vaccino P, Reyneri A (2015) Late-season nitrogen increases improver common and durum wheat quality. Agron J 107:680-690. https://doi.org/10.2134/agronj14.0405

Bodson B, Vancutsem F, Destain J et al. (2003) Evolution du fractionnement de la fumure azotée. In: CRA (ed) Livre Blanc "Céréales." FUSAGx, Gembloux (Belgique), pp 1-8

Brassard M (2007) Développement d'outils diagnostiques de la nutrition azotée du maïs-grain pour une gestion optimale de l'engrais azoté. Université de Laval, Québec

Casenave A, Valentin C (1989) Les états de surface de la zone sahélienne : influence sur l'infiltration, ORSTOM. Institut français de recherche scientifique pour le développement en Coopération, Paris

Defrance D, Ramstein G, Charbit S et al (2017) Consequences of rapid ice-sheet melting on the Sahelian population vulnerability. Proc Natl Acad Sci U S A 114:6533-6538. https://doi.org/ $10.1073 /$ pnas/.1619358114

Fageria NK, Baligar VC (1999) Yield and yield components of lowland rice as influenced by timing of nitrogen fertilization. J Plant Nutr 22:23-32. https://doi.org/10.1080/01904169909365603

Gnansounoua E, Dauriat A, Wyman C (2005) Refining sweet sorghum to ethanol and sugar: economic trade-offs in the context of North China. Bioresour Technol 96:985-1002. https:// doi.org/10.1016/j.biortech.2004.09.015

Gueye T, Sine B, Cisse N et al (2016) Characterization of phenotypic diversity of Sorghum collection for developing breeding material. Int J Sci 5:38-48. https://doi.org/10.18483/ ijSci.931

Hansen JW (2002) Realizing the potential benefits of climate prediction to agriculture: issues, approaches, challenges. Agric Syst 74:309-330. https://doi.org/10.1016/S0308-521X(02) 00043-4

Ingram KT, Roncoli MC, Kirshen PH (2002) Opportunities and constraints for farmers of west Africa to use seasonal precipitation forecasts with Burkina Faso as a case study. Agric Syst 74:331-349. https://doi.org/10.1016/S0308-521X(02)00044-6

IPCC (2007) Climate change 2007: impacts, adaptations and vulnerability. Contribution of working group II to the fourth assessment of the Intergovernmental Panel on Climate Change. Cambridge

Jones JW, Hoogenboom G, Porter CH et al (2003) The DSSAT cropping system model. Eur J Agron $18: 235-265$

Keating BA, Wafula BM, Watiki JM, Karanja DR (1993) Dealing with climatic risk in agricultural research - a case study modelling maize in semi-arid Kenya. In: Craswell ET, Simpson J (eds) Soil fertility and climatic constraints in dryland agriculture. ACIAR, Harare, pp 105-114

Kulkarni DP, Almodares A, Somani RB (1995) Sweet sorghum - supplementary sugar crop in Iran. Ann Plant Physiol 9:90-94

Legwaila GM, Balole TV, Karikari SK (2003) Review of sweet sorghum: a potential cash and forage crop in Botswana. J Agric For 12:5-14. https://doi.org/10.4314/uniswa.v12i1.4631

McCown RL, Wafula BM, Mohammed L et al (1991) Assessing the value of a seasonal rainfall predictor to agronomic decisions: the case of response farming in Kenya. In: Muchow RC, Bellamy JA (eds) Climatic risk in crop production. Models and management for the semi-arids tropics and subtropics. CAB Internatioanl, Wallingford, pp 383-409

Perez CM, Juliano B, Liboon SP et al (1996) Effects of late nitrogen fertilizer application on head rice yield, protein content, and grain quality of rice. Cereal Chem 73:556-560 
R Core Team (2017) R: a language and environment for statistical computing. R Foundation for Statistical Computing, Vienna

Rötter R, Van Keulen H (1997) Variations in yield response to fertilizer application in the tropics: II. Risks and opportunities for smallholders cultivating maize on Kenya's arable land. Agric Syst 53:69-95. https://doi.org/10.1016/S0308-521X(96)00037-6

Roudier P, Sultan B, Quirion P et al (2012) An ex-ante evaluation of the use of seasonal climate forecasts for millet growers in SW Niger. Int J Climatol 32:759-771. https://doi.org/10.1002/ joc. 2308

Schmidhuber J, Tubiello FN (2007) Global food security under climate change. Proc Natl Acad Sci U S A 104:19703-19708. https://doi.org/10.1073/pnas.0701976104

Sultan B, Gaetani M (2016) Agriculture in West Africa in the twenty-first century: climate change and impacts scenarios, and potential for adaptation. Front Plant Sci 7:1-20. https://doi.org/ $10.3389 /$ fpls.2016.01262

Sultan B, Barbier B, Fortilus J et al (2010) Estimating the potential economic value of seasonal forecasts in West Africa: a long-term ex-ante assessment in Senegal. Am Meteorol Soc 2:69-87. https://doi.org/10.1175/2009WCAS1022.1

Tubiello FN, Soussana J-F, Howden SM (2007) Crop and pasture response to climate change. Proc Natl Acad Sci U S A 104:19686-19690. https://doi.org/10.1073/pnas.0701728104

Wuest SB, Cassman KG (1992) Fertilizer-nitrogen use efficiency of irrigated wheat: I. Uptake efficiency of preplant versus late-season application. Agron J 84:682-688 